\title{
INVENTARISASI TANAMAN OBAT TRADISIONAL UNTUK PENDERITA DIABETES MELITUS DAN HIPERTENSI DI DESA MINANGAKECAMATAN BAMBANG KABUPATEN MAMASA
}

\author{
*)Herman, *)Murniati, *)Nur Aisyah Syaffitri S \\ *)Akademi Farmasi Sandi Karsa Makassar \\ *)Program Studi D-III Farmasi Sandi Karsa Makassar
}

\begin{abstract}
ABSTRAK
Telah dilakukan penelitian mengenai Inventarisasi Tanaman Obat Untuk Penderita Diabetes Melitus Dan Hipertensi yang bertujuan untuk mengetahui Bagaimana gambaran penggunaan tanaman obat diabetes melitus dan hipertensi yang digunakan oleh Masyarakat Desa Minanga Kecamatan Bambang Kabupaten Mamasa. Metode penelitian yang digunakan adalah deskriptif. Hasil penelitian ditemukan 11 jenis tanaman obat untuk Diabetes melitus dan 14 jenis tanaman obat untuk penyakit hipertensi yang digunakan oleh masyarakat di Desa Minanga Kecamatan Bambang Kabupaten Mamasa, bagian tumbuhan yang dominan digunakan adalah daun bagian lain yang digunakan yaitu akar, dan buah. Adapun acra pengolahan yang paling dominan adalah dengan merebus bagian tanaman.
\end{abstract}

Kata Kunci :Inventarisasi tanaman obat, antihipertensi, antidiabetes

\section{PENDAHULUAN}

\section{A. Latar Belakang}

Penyakit tidak menular hadir sebagai pembunuh utama sejak beberapa abad yang lalu. Penyakit degeneratif yang disebabkan oleh gaya hidup, kualitas lingkungan yang tidak sehat, dan kondisi psikologis, stres, atau depresi berkepanjangan, telah menjadi penyebab kematian tertinggi di seluruh dunia. Penyakit tidak menular menyerang orang dari semua umur, bagian terbesarnya adalah mereka yang berada dalam usian produktif (Kompayang Rata, dkk 2016).

World Health Organization (WHO) pada tahun 2012 dalam profil statistik Indonesia secara resmi merilis 10 penyakit penyebab kematian paling tinggi di Indonesia adalah penyakit Stroke (21\%), penyakit Jantung koroner (9\%), penyakit diabetes melitus (7\%), penyakit tuberculosis pernapasan (5\%), penyakit hipertensi (4\%), penyakit Cirrhosis (3\%), penyakit liver (3\%), penyakit cedera $(3 \%)$, penyakit pneumonia (3\%), penyakit diare (3\%) (WHO, 2012).

Data yang diperoleh dari Dinas Kesehatan Kota Makassar adapun 10(sepuluh) jenis penyakit penyebab utama kematian di Kota Makassar tahun 2015 adalah penyakit asma sebanyak 1.210 jiwa,penyakit jantung sebanyak 393 jiwa, penyakit hipertensi sebanyak 370 jiwa, penyakit diabetes melitus sebanyak 191 jiwa, penyakit broncho pneumonia sebanyak 122 jiwa, penyakit cedera sebanyak 76 jiwa, penyakit ginjal sebanyak 61 jiwa, dan penyakit TB paru sebanyak 57 jiwa (Dinkes Makassar 2016).

Hasil Riset Kesehatan Dasar 2013 prevalensi diabetes melitus di Indonesia berdasarkan jawaban pernah didiagnosis dokter sebesar $1,5 \%$ dan $0,4 \%$.
Diabetes melitus berdasarkan diagnosis atau gejala sebesar $2,1 \%$. Prevalensi hipertensi pada umur 18 tahun keatas di Indonesia sebesar 9,4\%, sedangkan yang pernah didiagnosis tenaga kesehatan atau sedang minum obat hipertensi sendiri sebesar 9,5\%. Prevalensi diabetes melitus dan hipertensi pada perempuan cenderung lebih tinggi dari pada laki-laki (Riskesdas 2013).

Berdasarkan data yang diperoleh dari Dinas Provinsi Sulawesi Barat adapun 10 (sepuluh) jenis penyakit penyebab utama kematian di Provinsi Sulawesi Barat tahun 2015 adalah penyakit diare 3.480 jiwa, penyakit kusta 2,400 jiwa, penyakit tuberculosi (TB paru) 540 jiwa, penyakit demam berdarah dengue 249 jiwa, penyakit Pneumonia 2.300 jiwa, penyakit hipertensi 320 . jiwa, penyakit diabetes melitus 130 jiwa, penyakit Gizi buruk 110 jiwa, penyakit Asma 540 jiwa (Dinkes Provinsi Sulbar, 2015)

Pemanfaatan tanaman obat masih banyak digunakan oleh masyarakat terutama dari kalangan menengah kebawah. Bahkan dari masa ke masa penggunaan tanaman obat mengalami perkembangan yang semakin meningkat, terlebih dengan munculnya isu kembali ke alam (back to nature) sementara itu banyak masyarakat beranggapan bahwa penggunaan tanaman obat atau obat tradisional relatif lebih aman dibandingkan obat sintetis. Namun demikian dalam perkembangannya sering dijumpai ketidaktepatan penggunaan tanaman berkhasiat obat karena kesalahan informasi maupun anggapan keliru terhadap tanaman obat dan cara penggunaanya (Katno, 2013).

Salah satu daerah yang banyak terdapat tumbuhan obat adalah Desa Minanga Kecamatan Bambang Kabupaten Mamasa, Masyarakat Desa 
Minanga masih menjaga tradisi leluhur dengan memanfaatkan tumbuhan, sebagai obat untuk mengobati berbagai macam penyakit diantaranya penyakit diabetes melitus dan penyakit hipertensi.

\section{B. Rumusan Masalah}

Berdasarkan latar belakang di atas, maka masalah dari penelitian ini adalah sebagai berikut:

1. Bagaimana gambaran penggunaan tanaman obat untuk penderita diabetes melitus yang digunakan oleh masyarakat Desa Minanga Kecamatan Bambang Kabupaten Mamasa?

2. Bagaimana gambaran penggunaan tanaman obat untuk penderita hipertensi yang digunakan oleh masyarakat Desa Minanga Kecamatan Bambang Kabupaten Mamasa?

\section{Tujuan Penelitian}

Adapun tujuan dari penelitian ini adalah sebagai berikut:

1. Untuk menggali potensi dan informasi masyarakat Desa Minanga Kecamatan Bambang Kabupaten Mamasa tentang pemanfaatan jenis dan bagian-bagian tanaman obat serta cara pengolahan tanaman obat untuk penderita hipertensi.

2. Untuk menggali potensi dan informasi masyarakat Desa Minanga Kecamatan Bambang Kabupaten Mamasa tentang pemanfaatan jenis dan bagian-bagian tanaman obat serta cara pengolahan tanaman obat untuk penderita diabetes melitus

\section{Manfaat Penelitian}

Memberi informasi dan menambah wawasan tentang tanaman obat tradisional, bagian-bagian tanaman obat, dan cara pengolahan tanaman obat yang dimanfaatkan masyarakat di Desa Minanga Kecamatan Bambang Kabupaten Mamasa sebagai alternatif pengobatan tradisional khususnya untuk penderita diabetes melitus dan hipertensi.

\section{METODE PENELITIAN}

\section{A. Jenis Penelitian}

Metode penelitian yang digunakan adalah deskriptif yaitu Inventarisasi tanaman obat tradisional untuk penderita diabetes melitus dan hipertensi.

\section{B. Waktu Dan Tempat Penelitian}

Penelitian ini dilakukan di Kecamatan Bambang Kabupaten Mamasa, Desa Minanga, dengan pengambilan data akan dilaksanakan pada bulan Maret 2019.

\section{Tekhnik Pengumpulan Data}

Tekhnik pengumpulan data yang digunakan pada penelitian adalah dalam bentuk wawancara.
Sementara Rancangan Penelitian yang dilakukan yaitu;

a. Penelitian lapangan (Field Research),yakni berupa kusioner untuk mengetahui gambaran yang nyata menganai pengatahuan masyarakat tentang penggunaan obat tradisional sebagai obat hipertensi dan diabetes melitus.

b. Penelitian kepustakaan (Library Research), yakni menggunakan buku-buku yang berhubungan dengan masalah-masalah yang dihadapi.

\section{Populasi dan Sampel}

1. Populasi

Populasi dalam penelitian ini adalah masyarakat Desa Minanga Kecamatan Bambang Kabupaten Mamasa

2. Sampel

Sampel merupakan obyek yang diteliti yang diannggap mewakili seluruh populasi (Notoadmojo melitusojo, 2010). Teknik pengumpulan data yang digunakan pada penelitian ini adalah dalam bentuk wawancara.

Metode pengambilan sampel yang dipilih adalah Accidental Sampling (Supardi S.Surahman, 2014). Dengan Kriteria Pengambilan Sampel yaitu;

a. Berusia 18 tahun keatas

b. Pernah menggunakan obat tradisional sebagai obat hipertensi dan diabetes melitus

c. Bersedia di wawancara

Adapun penentuan jumlah sampel dengan menggunakan rumus slovin yaitu :

Diketahui, Jumlah Populasi $(\mathrm{N})=260$

Batas toleransi kesalahan (e) $=10 \%(0,01)$

Maka jumlah sampel adalah :

$$
\begin{aligned}
& n=\frac{N}{1+N(e)^{2}} \\
& n=\frac{260}{1+260(0,1)^{2}} \\
& n=\frac{260}{1+2,6} \\
& n=\frac{260}{3,6}=72,22 \\
& n=72
\end{aligned}
$$

\section{HASIL DAN PEMBAHASAN}

\section{A. Hasil Penelitian}

Pengumpulan data hasil penelitian yang dilakukan di Desa Minanga Kecamatan Bambang Kabupaten Mamasa yang dilaksanakan pada bulan Maret 2019 dengan jumlah responden 69 orang diperoleh 11 jenis tanaman obat hasil wawancara 
tentang tanaman obat pilihan masyarakat sebagai obat antidiabetes dan 14 jenis tanaman obat hasil wawancara tentang tanaman obat pilihan masyarakat yang digunakan sebagai obat antihipertensi

Tabel I. Daftar jenis tanaman dan metode pengolahan yang digunakan sebagai obat diabetes melitus oleh Masyarakat Desa Minanga Kecamatan Bambang Kabupaten Mamasa

\begin{tabular}{|c|c|c|c|c|}
\hline No & $\begin{array}{c}\text { Nama } \\
\text { Tanaman }\end{array}$ & Nama Asal & $\begin{array}{c}\text { Frekuensi } \\
\text { Penggunaan }\end{array}$ & $\begin{array}{c}\text { Metode } \\
\text { Pengolahan }\end{array}$ \\
\hline 1 & $\begin{array}{l}\text { Daun } \\
\text { Sambiloto } \\
\text { (Andrographis } \\
\text { paniculata } \\
\text { Ness) }\end{array}$ & $\begin{array}{c}\text { Daum } \\
\text { sambiloto }\end{array}$ & 10 & Direbus \\
\hline 2 & $\begin{array}{l}\text { Mahkota Dewa } \\
\text { (Phaleria } \\
\text { macrocarpa) }\end{array}$ & Mahkota Dewa & 5 & Ditumbuk \\
\hline 3 & $\begin{array}{l}\text { Daun Sirih } \\
\text { Merah(Piper } \\
\text { ornatum) }\end{array}$ & $\begin{array}{c}\text { Daum Baulu } \\
\text { Malea }\end{array}$ & 7 & Direbus \\
\hline 4 & $\begin{array}{l}\text { Pare } \\
\text { (Momordica } \\
\text { charantia) }\end{array}$ & Paria & 3 & Ditumbuk \\
\hline 5 & $\begin{array}{l}\text { Daun kelor } \\
\text { (Moringa } \\
\text { oleifera) }\end{array}$ & Daum kelor & 3 & Direbus \\
\hline 6 & $\begin{array}{l}\text { Daun Bandotan } \\
\text { (Ageratumcony } \\
\text { zoides) }\end{array}$ & $\begin{array}{c}\text { Daum } \\
\text { Tamesambuk }\end{array}$ & 3 & Direbus \\
\hline 7 & $\begin{array}{l}\text { Buah } \\
\text { mengkudu } \\
\text { (Morinda } \\
\text { citrifolia) } \\
\end{array}$ & $\begin{array}{c}\text { Buah } \\
\text { mengkudu }\end{array}$ & 3 & Direbus \\
\hline 8 & $\begin{array}{l}\text { Daun Kemangi } \\
\text { (Ocimum } \\
\text { basillicum) }\end{array}$ & Daum camangi & 3 & Direbus \\
\hline 9 & $\begin{array}{l}\text { Daun Salam } \\
\text { (Syzygium } \\
\text { polyanthum) }\end{array}$ & Daun salam & 4 & Direbus \\
\hline 10 & $\begin{array}{l}\text { Daun } \\
\text { Binahoang } \\
\text { (Basella rubra } \\
\text { L.) }\end{array}$ & $\begin{array}{c}\text { Daum } \\
\text { binahoam }\end{array}$ & 4 & Direbus \\
\hline 11 & $\begin{array}{l}\text { Daun Murbei } \\
\text { (Morus alba L.) }\end{array}$ & $\begin{array}{c}\text { Daum keak- } \\
\text { keak }\end{array}$ & 1 & Direbus \\
\hline
\end{tabular}

Dari tabel diatas dapat dilihat dari 69 orang responden ternyata terdapat responden yang menggunakan lebih dari satu jenis tanaman obat. ada 11 jenis tanaman obat yang pernah dikonsumsi oleh masyarakat yaitu, 10 orang menggunakan daun sambiloto, 5 orang menggunakan buah mahkota dewa, 7 orang menggunakan daun sirih merah, 3 orang yang menggunakan buah pare, 3 orang menggunakan daun kelor, 3 orang menggunakan daun bandotan, 3 orang menggunakan buah mengkudu, 3 orang menggunakan daun kemangi, 4 orang menggunakan daun salam, 4 orang menggunakan daun binahoang, dan 1 orang menggunakan daun murbei

Tabel II. Daftar jenis tanaman obat, bagian tanaman yang digunakan, dan pemakainnya yang digunakan sebagai obat diabetes melitus oleh Masyarakat Desa Minanga Kecamatan Bambang Kabupaten Mamasa

\begin{tabular}{|c|c|c|c|}
\hline No. & Nama Tanaman Obat & $\begin{array}{c}\text { Bagian } \\
\text { Tanaman } \\
\text { Yang Diolah }\end{array}$ & Pemakain \\
\hline 1. & $\begin{array}{l}\text { Daun Sambiloto } \\
\text { (Andrographis paniculata } \\
\text { Ness) }\end{array}$ & Daun & Tunggal \\
\hline 2 & $\begin{array}{l}\text { Mahkota Dewa (Phaleria } \\
\text { macrocarpa) }\end{array}$ & Buah & Tunggal \\
\hline 3 & $\begin{array}{l}\text { Daun Sirih Merah (Piper } \\
\text { ornatum) }\end{array}$ & Daun & Tunggal \\
\hline 4 & Pare (Momordica charantia) & Buah & Campuran \\
\hline 5 & Daun Kelor (Moringa oleifera) & Daun & Tunggal \\
\hline 6 & $\begin{array}{l}\text { Daun Bandotan (Ageratum } \\
\text { conyzoides) }\end{array}$ & Daun & Campuran \\
\hline 7 & $\begin{array}{l}\text { Buah mengkudu (Morinda } \\
\text { citrifolia) }\end{array}$ & Buah & Tunggal \\
\hline 8 & $\begin{array}{l}\text { Daun Kemangi (Ocimum } \\
\text { basillicum) }\end{array}$ & Daun & Campuran \\
\hline 9 & $\begin{array}{l}\text { Daun Salam (Syzygium } \\
\text { polyanthum) }\end{array}$ & Daun & Tunggal \\
\hline 10 & $\begin{array}{l}\text { Daun Binahoang (Basella } \\
\text { rubra Linn) }\end{array}$ & Daun & Campuran \\
\hline 11 & Daun Murbei (Morus alba L) & Daun & Campuran \\
\hline
\end{tabular}

Dari tabel diatas diperoleh data bagian tanaman obat yang digunkan untuk mengobati penyakit diabetes melitus adalah daun dengan frekuensi 8 , buah 3 , pemakaian yang digunakan adalah tunggal dengan ferekuensi 6, campuran dengan frekuensi 5 .

Tabel III. Daftar jenis tanaman dan metode pengolahan yang digunakan sebagai obat hipertensi oleh masyarakat Desa Minanga Kecamatan Bambang Kabupaten Mamasa

\begin{tabular}{|c|c|c|c|c|}
\hline No & $\begin{array}{c}\text { Nama } \\
\text { Tanaman }\end{array}$ & Nama Asal & $\begin{array}{c}\text { Frekuensi } \\
\text { Penggunaan }\end{array}$ & $\begin{array}{c}\text { Metode } \\
\text { Pengolahan }\end{array}$ \\
\hline 1 & $\begin{array}{l}\text { Daun Alpukat } \\
\text { (Persea } \\
\text { americana) }\end{array}$ & $\begin{array}{l}\text { Daum } \\
\text { apokak }\end{array}$ & 2 & Direbus \\
\hline 2 & $\begin{array}{l}\text { Daun sirsak } \\
\text { (Annona } \\
\text { muricata L.) }\end{array}$ & $\begin{array}{l}\text { Daum } \\
\text { Sirsak }\end{array}$ & 3 & Direbus \\
\hline 3 & $\begin{array}{l}\text { Buah } \\
\text { Mengkudu } \\
\text { (Morinda } \\
\text { Citrifolia) }\end{array}$ & $\begin{array}{c}\text { Buah } \\
\text { mengkudu }\end{array}$ & 4 & Ditumbuk \\
\hline 4 & $\begin{array}{l}\text { Belimbing } \\
\text { Wuluh } \\
\text { (Averrhoa } \\
\text { bilimbi) }\end{array}$ & Belimbing & 1 & Direbus \\
\hline 5 & $\begin{array}{l}\text { Daun Kumis } \\
\text { Kucing } \\
\text { (Orthosiphon } \\
\text { aristatus Benth } \\
\text { (Blume) Miq.) }\end{array}$ & $\begin{array}{l}\text { Daum } \\
\text { kumis } \\
\text { kucing }\end{array}$ & 11 & Direbus \\
\hline 6 & $\begin{array}{l}\text { Seledri (Apium } \\
\text { graveolens) }\end{array}$ & Seledri & 2 & Direbus \\
\hline 7 & $\begin{array}{l}\text { Labu Siam } \\
\text { (Sechium edule) }\end{array}$ & Rabisa & 2 & Diparut \\
\hline
\end{tabular}




\begin{tabular}{clccc}
\hline 8 & $\begin{array}{l}\text { Bawang Putih } \\
\text { (Aliium } \\
\text { sativum) }\end{array}$ & $\begin{array}{l}\text { Lessuna } \\
\text { mabusa }\end{array}$ & 2 & Diparut \\
\hline 9 & $\begin{array}{l}\text { Kulit Manggis } \\
\text { (Garcinia } \\
\text { mangostana } \text { L) }\end{array}$ & $\begin{array}{c}\text { Daum } \\
\text { manggis }\end{array}$ & 3 & Direbus \\
\hline 10 & $\begin{array}{l}\text { Daun Pepaya } \\
\text { (Carica } \\
\text { papaya) }\end{array}$ & Daum Loka & 4 & Direbus \\
\hline 11 & $\begin{array}{l}\text { Daun Pegagan } \\
\text { (Cantella } \\
\text { asiatica) }\end{array}$ & $\begin{array}{c}\text { Daum } \\
\text { panggaga }\end{array}$ & 9 & Direbus \\
\hline 12 & $\begin{array}{l}\text { Daun Murbei } \\
\text { (Morus alba } \text { L) }\end{array}$ & $\begin{array}{c}\text { Daum } \\
\text { keak-keak }\end{array}$ & 2 & Direbus \\
\hline 13 & $\begin{array}{l}\text { Daun Sambung } \\
\text { Nyawa }(G y n u r a \\
\text { procumbens })\end{array}$ & $\begin{array}{c}\text { Daum } \\
\text { Sambum } \\
\text { Penaha }\end{array}$ & 2 & Direbus \\
\hline 14 & $\begin{array}{l}\text { Akar Alang- } \\
\text { Alang } \\
\text { (Imperata } \\
\text { cylindrica) }\end{array}$ & $\begin{array}{c}\text { Akak } \\
\text { alang-alang }\end{array}$ & 2 & Direbus \\
\hline
\end{tabular}

Dari Tabel diatas dapat dilihat ada 14 jenis tanaman obat yang pernah dikonsumsi masyarakat yaitu, 2 orang menggunakan daun alpukat, 3 orang menggunakan daun Sirsak, 4 orang menggunakan buah mengkudu, 1 orang menggunakan belimbing wuluh, 11 orang mengggunakan daun kumis kucing, 2 orang menggunakan seledri, 2 orang menggunakan labu siam, 2 orang menggunakan bawang putih, 3 orang menggunakan kulit manggis, 4 orang menggunakan daun pepaya, 9 orang menggunakan daun pegagan, 2 orang menggunakan daun murbei, 2 orang menggunakan daun sambung nyawa, 2 orang menggunakan akar alang-alang.

Tabel IV. Daftar jenis tanaman obat, bagian tanaman yang digunakan, dan pemakaiannya yang digunakan sebagai obat hipertensi oleh Mayarakat Desa Minanga Kecamatan Bambang Kabupaten Mamasa

\begin{tabular}{|c|c|c|c|}
\hline No & Nama Tanaman Obat & $\begin{array}{c}\text { Bagian } \\
\text { Tanaman } \\
\text { Yang Diolah }\end{array}$ & Pemakaian \\
\hline 1 & $\begin{array}{l}\text { Daun Alpukat (Persea } \\
\text { americana Mill) }\end{array}$ & Daun & Tunggal \\
\hline 2 & $\begin{array}{l}\text { Daun Sirsak (Annona } \\
\text { Muricata L.) }\end{array}$ & Daun & Tunggal \\
\hline 3 & $\begin{array}{l}\text { Buah Mengkudu } \\
\text { (Morinda Citrifolia) }\end{array}$ & Buah & Tunggal \\
\hline 4 & $\begin{array}{l}\text { Belimbing Wuluh } \\
\text { (Averrhoa bilimbi) }\end{array}$ & Buah & Tunggal \\
\hline 5 & $\begin{array}{l}\text { Daun Kumis Kucing } \\
\text { (Orthosiphon aristatus } \\
\text { (Blume) Miq.) }\end{array}$ & Daun & Tunggal \\
\hline 6 & $\begin{array}{l}\text { Seledri (Apium } \\
\text { graveolens) }\end{array}$ & Daun & Campuran \\
\hline 7 & $\begin{array}{l}\text { Labu Siam (Sechium } \\
\text { edule) }\end{array}$ & Buah & Tunggal \\
\hline 8 & $\begin{array}{l}\text { Bawang Putih (Aliium } \\
\text { sativum) }\end{array}$ & Buah & Campuran \\
\hline 9 & $\begin{array}{l}\text { Kulit Manggis (Garcinia } \\
\text { mangostana L) }\end{array}$ & Daun & Tunggal \\
\hline 10 & $\begin{array}{l}\text { Daun Pepaya (Carica } \\
\text { papaya) }\end{array}$ & Daun & Tunggal \\
\hline 11 & $\begin{array}{l}\text { Daun Pegagan (Cantella } \\
\text { asiatica) }\end{array}$ & Daun & Tunggal \\
\hline 12 & $\begin{array}{l}\text { Daun Murbei (Morus } \\
\text { alba L) }\end{array}$ & Daun & Tunggal \\
\hline
\end{tabular}

\begin{tabular}{|c|c|c|c|}
\hline 13 & $\begin{array}{l}\text { Daun Sambung Nyawa } \\
\text { (Gynura procumbens) }\end{array}$ & Daun & Tunggal \\
\hline 14 & $\begin{array}{l}\text { Akar Alang-Alang } \\
\text { (Imperata cylindrica) }\end{array}$ & Akar & Tunggal \\
\hline
\end{tabular}

Dari tabel diatas diperoleh data bagian tanaman yang digunakan sebagai obat antihipertensi adalah daun dengan frekuensi 9, buah 4, dan akar 1 . Pemakaian yang digunakan adalah tunggal dengan frekuensi 12, Campuran dengan frekuensi 2.

\section{B. Pembahasan}

Penelitian yang dilakukan di Desa Minanga Kecamatan Bambang Kabupaten Mamasa telah dilaksanakan pada bulan Maret 2019 dengan jumlah responden sebanyak 69 orang, diperoleh 11 jenis tanaman yang digunakan sebagai obat antidiabetes, dan 14 jenis tanaman yag digunakan sebagai obat antihipertensi

Tanaman obat yang digunakan oleh masyarakat Desa Minanga untuk mengobati penyakit diabetes melitus adalah daun sambiloto, daun sirih merah, mahkota dewa, daun binahoang, buah pare, daun kelor, daun bandotan, daun kemangi, daun salam, buah mengkudu, dan daun murbei.

Daun Sambiloto dengan nama latin Andrographis paniculata adalah salah satu tanaman obat yang paling banyak digunakan oleh masyarakat Desa Minanga sebagai obat antidiabetes karena Masyarakat Desa minanga meyakini bahwa daun sambiloto sangat ampuh dalam menurunkan kadar gula darah selain itu daun sambiloto juga mudah ditemukan. Daun samibiloto biasanya tumbuh disekitar tempat yang lembab bertangkai pendek, warna hijau tua, tepian daun rata dan ujung daun beserta pangkal daunnya meruncing. kandungan zat aktif pada daun sambiloto yaitu Andrographolide dan glikosida di terpen. Andrographolide merupakan senyawa aktif anti bakteri, dan anti diabetes. Andrographolide ini adalah senyawa utama dalam daun sambiloto yang memiliki fungsi dalam menurunkan kadar glukosa dalam darah .cara pengolahannya pun sangatlah mudah dengan menyediakan daun sambiloto segar beberapa helai, rebus 1 liter air yang sudah berisi sambiloto hingga mendidih tunggu hingga tersisa satu gelas dan tidak terlalu panas, kemudian konsumsi secara rutin. Cara penggunaannya yaitu tunggal.

Daun sirih merah dengan nama latin Piper ornatumjuga merupakan salah satu tanaman obat yang paling banyak digunakan oleh Masyarakat Desa Minanga sebagai obat antidiabetes karena masyarakat meyakini khasiat dari tanaman ini dapat menurunkan kadar gula darah dan telah diakui oleh masyarakat sebagai obat antidiabetes yang paling ampuh. Daun sirih merah mengandung alkaloid, saponin, tanin, dan flavonoid. Senyawa alkaloid dan flavonoid mempunyai aktivitas hipoglikemik atau penurun kadar glukosa darah. Cara 
pengolahannya yaitu siapkan 3 lembar daun sirih merah setengah tua cuci bersih kemudian iris kecilkecil. Rebus dengan air sebanyak tiga gelas sampai mendidih minum tiga kali sehari sebelum makan. Cara penggunaannya yaitu Tunggal.

Tanaman obat yang juga digunakan sebagai obat antidiabetes oleh Masyarakat yaitu mahkota dewa dengan nama latin Phaleria macrocarpa karena dianggap sangat ampuh menurunkan kadar gula darah. buah Mahkota dewa mengandung senyawa golongan alkaloid, saponin, flavonoid, dan polifenol. Senyawa safonin inilah yang berkhasiat sebagai antidiabetes. Cara pengolahannya yaitu ambil minimal 3 buah mahkota dewa lalu bersihkan kemudian tumbuk sampai halus kemudian ditambahkan dua gelas air kemudian saring, jika sudah disaring kemudian ambil airnya lalu diminum. Cara penggunaanya yaitu Tunggal tidak memadukan obat dari dokter

Daun binahoang dengan nama latin Basella rubra Linn juga digunakan oleh masyarakat sebagai obat antidiabetes Kandungan yang terdapat dalam daun binahoang diantaranya saponin, alkaloid, asam oleanotik, minyak atsiri, asam askorbat, dan antioksidan. Zat yang berfungsi menurunkan kadar gula darah dalam tubuh adalah alkaloid. Cara pengolahannya yaitu ambil 11 lembar daun binahoang yang masi segar, cuci bersih, rebus didalam panci dengan air tiga gelas, jika mendidih dan tersisa dua gelas air kemudian didinginkan setelah itu diminum dapat dikonsumsi 1 kali sehari. Cara penggunaannya yaitu campuran dari obat modern atau obat dokter yaitu obat moderen diminum terlebih dahulu setelah 1 sampai 2 jam kemudian diminum obat tradisional.

Buah pare dengan nama latin Momordica charantia merupakan salah satu tanaman yang juga digunakan masyarakat sebagai obat antidiabetes. Zat aktif yang terdapat dalam buah pare yaitu charantin, alkaloid, vicine, dan peptida dapat memicu aktivitas pelepasan insulin yang lebih baik sekaligus melawan resistensi insulin. Cara pengnaannya yaitu ambil dua buah pare, kemudian ditumbuk, setalah halus ditambahkan dua gelas air, kemudian disaring, kemudian disisahkan satu gelas dan diminum dua kali sehari. Cara penggunaannya yaitu campuran dari obat modern atau obat dokter yaitu obat modern diminum terlebih dahulu setelah 1 sampai 2 jam kemudian diminum obat tradisional

Daun kelor dengan nama latin Moringa oleifera salah satu tanaman yang digunakan Masyarakat sebagai obat antidiabetes, Kandungannya yaitu vitamin C, kalsium, flavonoid, vitamin A, alkaloid, protein, kolkisin, vitamin B2, pottasium. Cara pengolahannya yaitu siapkan satu genggam daun kelor cuci dengan air hingga bersih tambahkan air tiga gelas rebus hingga mendidih dan tersisa satu gelas, kemudian saring, lalu minum air rebusan tersebut 3 kali sehari masing-masing satu gelas. Cara penggunaannya yaitu tunggal tidak memadukan obat dari dokter.

Daun bandotan dengan nama latin Ageratum conyzoides salah satu tanaman yang digunakan Mayarakat sebagai obat antidiabetes, adapuncara penggunaannya yaitu ambil daun bandotan 3 lembar, kemudian cuci bersih, lalu rebus sampai mendidih, kemudian ambil air yang sudah direbus lalu minum 2 kali sehari masing-masing satu gelas. Cara penggunaanya yaitu campuran dari obat modern atau obat dokter yaitu obat modern diminum terlebih dahulu setelah 1 sampai 2 jam kemudian diminum obat tradisional.

Daun kemangi dengan nama latin Ocimum basilicum. Cara pengolahannya yaitu siapkan daun kemangi yang segar, cuci bersih, tambahkan air satu gelas lalu rebus hingga mendidih, setelah mendidih saring dan minum air yang sudah direbus 1 kali sehari. Cara penggunaannya yaitu campuran dari obat modern atau obat dokter yaitu obat modern diminum terlebih dahulu setelah satu sampai dua jam kemudian diminum obat tradisional

Daun salam dengan nama latin Sizygium polyanthum. Cara pengolahan yaitu ambil 7 lembar daun salam cuci hingga bersih, rebus daun salam hingga mendidih, angkat air rebusan, saring, dan minum 2 kali sehari. Cara penggunaannya yaitu tunggal tidak memadukan obat dari dokter.

Buah mengkudu dengan nama latin Morinda citrifolia. Cara pengolahannya yaitu bersihkan buah mengkudu dengan air bersih setelah itu rebus buah mengkudu dengan air tiga gelas sampai mendidih dan jumlah air berkurang menjadi satu gelas lalu airnya diminum. Cara penggunaannya yaitu tunggal tidak memadukan obat dari dokter.

Daun murbei dengan nama latin Morus alba L. Cara pengolahannya yaitu ambil daun murbei, kemudian bersihkan, lalu rebus hingga mendidih, lalu ambil airnya yang sudah direbus lalu diminum 1 kali dalam sehari. Cara penggunaannya yaitu campuran dari obat modern atau obat dokter yaitu obat modern diminum terlebih dahulu setelah satu sampai dua jam kemudian obat tradisional di minum.

Tanaman obat yang paling banyak digunakan sebagai obat antihipertensi oleh masyarakat Desa Minanga adalah daun kumis kucing, daun pegagan, buah mengkudu, daun pepaya, daun Sirsak, kulit manggis, daun alpukat, belimbing wuluh, selsedri, labu siam, bawang putih, daun murbei, sambung nyawa, dan akar alng-alang.

Daun kumis kucing dengan nama latin orthosiphon aristatus adalah tanaman obat yang paling banyak digunakan oleh masyarakat Desa Minanga sebagai obat antihipertensi karena Masyarakat meyakini bahwa tanaman ini sangat ampuh dalam menurunkan tekanan darah dan telah diakui sebagai penurun darah yang paling berkhasiat. daun kumis kucing memiliki kandungan alami diantaranya sinensetin, Zat semak, Saponin, 
Minyak atsiri, Sapofonin, Minositol, Kalium kandungan diatas adalah senyawa alami yang terkandung di dalam tanaman kumis kucing, dari senyawa tersebut dapat dimanfaatkan sebagai obat antidiabetes. Cara pengolahannya yaitu sediakan daun kumis kucing sebanyak 20 lembar masukkan dalam air $150 \mathrm{ml}$ dan panaskan dengan api kecil hingga menjadi $100 \mathrm{ml}$. Minum 3 kali sehari. Cara penggunaanya yaitu tunggal tidak memadukan obat dari dokter.

Daun Pegagan dengann nama latin Centella asiatica merupakan salah satu tanaman obat yang paling banyak digunakan oleh Masyarakat Desa Minanga sebagai obat antidiabetes karena dipercaya ampuh dalam meenurukan tekanan darah. Pegagan merupakan tanaman liar yang mempunyai prospek cukup baik sebagai tanaman obat. Pegagan mengandung beberapa senyawa bioaktif seperti glikosida, yang banyak digunakan dalam ramuan obat tradisional. Cara pengolahannya yaitu ambil satu genggam daun pegagan cuci bersih masukkan ke dalam panci bersama satu gelas air setelah itu rebus sampai mendidih selanjutnya saring airnya angakt dan minum air ramuan tersebut secara rutin sehari 2 kali pagi dan sore. Cara penggunaannya yaitu tunggal tidak memadukan obat dari dokter

Buah mengkudu dengan nama latin Morinda citrifolia. Cara pengolahannya yaitu bersihkan buah mengkudu dengan air bersih setelah itu rebus buah mengkudu dengan air tiga gelas sampai mendidih dan jumlah air berkurang menjadi satu gelas lalu airnya diminum. Cara penggunaannya yaitu tunggal tidak memadukan obat dari dokter.

Daun Pepaya dengan nama latin Carica papaya L. Cara pengolahannya siapkan tiga lembar daun pepaya mudah cuci bersih kemudian tambahkan air, saring ramuan tersebut dan minum duan kali sehari pagi dan sore. Cara penggunannya yaitu tunggal tidak memadukan obat dari dokter.

Daun Sirsak dengan nama latin Anonna muricata L. Cara pengolahannya ambil daun sirsak 7 lembar kemudian tambahkan air rebus sampai mendidihkan sisa airnya satu gelas minum airnya dua kali sehari. Cara penggunaannya yaitu tunggal tidak memadukan obat dari dokter.

Kulit manggis dengan nama latin Garcinia mangostana. Cara pengolahannya siapkan 5 buah kulit manggis yang telah dikeringkan terlebih dahulu cuci kulit manggis hingga bersih, lalu halus kulit manggis hingga kulit manggis benar-benar hancur, rebus hingga mendidih, minum ramuan kulit manggis dua kali sehari. Cara penggunannya yaitu tunggal tidak memadukan obat dari dokter.

Daun Alpukat dengan nama latin Tersea americana. Cara pengolahannya yaitu sediakan lima sampai tujuh lembar daun alpukat cuci hingga bersih, tambahkan dua gelas air putih rebus sampai mendidih hingga berkurang setengahnya, setelah hangat rebusan tadi disaring lalu minum air rebusan alpukat secara rutin. Cara penggunannya yaitu campuran dari obat modern atau obat dokter.

Daun Belimbing wuluh dengan nama latin Averrhoa belimbi.Cara pengolahannya yaitu cuci belimbing wuluh hingga bersih potong belimbing wuluh hingga menjadi kecil kemudian rebus, lalu tunggu hingga air tersisa sepertiga bagian saja minum dua kali sehari. Cara penggunannya yaitu campuran dari obat modern atau obat dokter yaitu obat modrn diminum terlebih dahulu setelah satu sampai dua jam kemudian diminum obat tradisional.

Daun seledri dengan nama latin Avium graveolens. Cara pengolahannya yaitu Siapkan seledri secukupnya bersihkan, kemudian potongpotong tambahkan air, kemudian rebus, dikomsumsi dua kali sehari hingga tekanan darah membaik. Cara penggunannya yaitu campuran dari obat modern atau obat dokter yaitu obat modern diminum terlebih dahulu setelah satu sampai dua jam kemudian diminum obat tradisional.

Labu Siam dengan nama latin Sechium edule. Cara pengolahannya yaitu ambil satu Labu Siam kemudian dicuci bersih, diparut dan ditambahkan air kemudian disaring, selanjutnya hasil saringan tersebut diminum dua kali sehari. Cara penggunaannya yaitu tunggal tidak memadukan obat dari dokter.

Bawang Putih dengan nama latin Aliium sativum. Siapkan beberapa siung bawang putih cuci bersih, parut bawang putih sampai halus, campurkan bawang putih yang sudah halus dengan air lalu peras, minumlah air saringannya setiap pagi sampai sembuh. Cara penggunannya yaitu campuran dari obat modern atau obat dokter yaitu obat modern diminum terlebih dahulu setelah satu sampai dua jam kemudian diminum obat tradisional.

Daun murbei dengan nama latin Morus alba L. Cara pengolahannya yaitu ambil daun murbei, kemudian bersihkan, lalu rebus hingga mendidih, lalu ambil airnya yang sudah direbus lalu diminum 1 kali dalam sehari. Cara penggunaannya yaitu tunggal tidak memadukan obat modern.

Daun Sambung nyawa dengan nama latin Gymura procumbens. Cara pengolahannya yaitu ambil 7 sampai 12 daun sambung nyawa kemudian cuci bersih rebus sisahkan 1 gelas airnya kemudian minum 1 kali dalam sehari. Cara penggunaannya yaitu tunggal tidak memadukan obat dari dokter.

Akar alang-alang dengan nama latin Imperata cylindrica. Cara pengolahannya ambil akar alangalang kemudian keringkan lalu cuci sampai bersih, kemudian rebus hingga mendidih lalu minum airnya yang sudah direbus dua kali sehari. Cara penggunannya yaitu tunggal tidak memadukan dengan obat modern.

Sesuai hasil wawancara masyarakat menggunakan dua pengobatan yaitu obat tradisional dan obat modern, Masyarakat lebih banyak yang 
menggunakan obat tradisional dikarenakan mudah di dapat, aman digunakan, karena memiliki efek samping yang kecil dan penggunaannya mudah. Masyarakat mendapatkan tanaman obat di kebun karena biasanya banyak terdapat tumbuh-tumbuhan yang tumbuh liar di kebun masyarakat. Selain itu ada pula yang sengaja menanam tanaman tetapi bukan untuk tujuan obat diabetes melitus dan hipertensi melainkan hanya untuk dikonsumsi buahnya selama ini masyarakat tidak pernah merasakan ada efek samping yang merugikan selama mengonsumsi tanaman obat yang ada hanyalah manfaat yaitu menurunkan tekanan darah dan gula darah.

\section{PENUTUP}

\section{Kesimpulan}

1. Terdapat 11 jenis tanaman obat yang digunakan oleh Masyarakat Desa Minanga Kecamatan Bambang Kabupaten Mamasa sebagai obat diabetes melitus. Dan ada 14 jenis tanaman yang digunakan sebagai obat hipertensi.

2. Bagian tanaman yang paling banyak digunakan yaitu daun dan buah Metode pengolahan yang digunakan yaitu direbus, diparut, dan ditumbuk. Pemakainnya ada yang tunggal dan ada yang campuran. Adapun alasan penggunaan obat tradisional dengan tanaman obat yaitu, kepercayaan, mudah ditemukan, dan tidak memerlukan banyak biaya.

\section{Saran}

1. Disarankan untuk dilakukan penelitian lebih lanjut uji efek terhadap kandungan kimia dari tanaman obat yang paling banyak digunakan oleh Masyarakat Desa Minanga Kecamatan Bambang Kabupaten Mamasa

2. Diharapakan kepada peneliti selanjutnya untuk meneliti dan menginventarsasikan tanaman obat tradisional yang terdapat di daerah masing-masing agar dapat menambah pengetahuan tentang obat tradisional.

\section{DAFTAR PUSTAKA}

Bustan M. N. 2007. Epidemiologi Penyakit Tidak

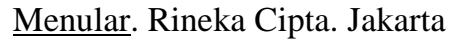

Badan Pusat Statistik Kabupaten Mamasa. 2017. Kabupaten Mamasa Dalam Angka 2017. BPS Kabupaten Mamasa. Mamasa

Dinas Kesehatan Provinsi Sulawesi Selatan. 2016. Profil Kesehatan Kota Makassar Tahun 2015. Makassar
Dinas Kesehatan Provinsi Sulawesi Barat. Kota Mamasa. 2015. Profil Kesehatan Kota Mamasa Tahun 2015. Mamasa

Johar Arifin. 2017. SPSS24 Untuk Penelitian Dan Skripsi. PT. Gramedia. Jakarta

Kartasapoetra. 2006. Budidaya Tanaman Berkhasiat Obat. Rineka Cipta. Jakarta

Media Agro Redaksi. 2008. Buku Pintar Tanaman Obat. PT. Agromedia Pustaka. Jakarta

Hidayat Syamsul, Napitupulu M.Rodame. 2015. Kitab Tumbuhan Obat. Agriflo. Jakarta

Notoadmojo S. 2010. Metodologi Penelitian Kesehatan Edisi Revisi. Rineka Cipta. Jakarta

Riset Kesehatan Dasar Laporan Provinsi Sulawesi Selatan. 2013. Badan Penelitian Dan Pengembangan Kesehatan Departemen Kesehatan RI. Jakarta

Sholeh Chabib Dkk. 2010. Management Aset Pariwisata. Guardaya Intimarta. Bandung

Siregar, D. 2004. Management Aset Pariwisata. Guardaya Intirmata. Bandung

Supardi, S.S. 2014. Metodologi Penelitian Untuk Mahasiswa Farmasi. Trans Indo Media; Jakarta

Tjay Hoan Tan Dkk. 2007. Obat-obat Penting. Jakarta. PT. Gramedia. Jakarta

Tjandrawinata Raymond. 2012. Medicinus Hipertension. Vol. 25. No. 1. Tangerang

WaluyoSrikandi. 2009. 100 Question \& Answer Diabetes. PT. Gramedia.Jakarta 